\title{
Determinants of the Swiss Franc Real Exchange Rate
}

\author{
Tommaso Mancini Griffoli ${ }^{b}$, Christoph Meyer ${ }^{c}$, Jean-Marc Natal ${ }^{\mathrm{d}}$ and \\ Attilio Zanetti ${ }^{\mathrm{e}}$
}

\section{JEL Classification: C33, F31}

Keywords: real exchange rate, Swiss franc, government consumption, terms of trade, net foreign assets, GDP per capita, Balassa-Samuelson, productivity, DOLS.

\section{Introduction}

The Swiss franc is a well-known safe-haven currency. Its short-run reaction patterns in periods of uncertainty have been documented in detail by De BocK and De Carvahlo Finlo (2013) as well as Ranaldo and Soederlin (2010). Less known are the determinants of the Swiss franc long-run behaviour in real terms.

Economists agree that in the long run the real exchange rate is determined by fundamental factors, such as wealth, consumer preferences, productivity growth, demography or institutional changes. As these factors evolve over time they will drive the real exchange rate in one direction or the other. Economic theory, however, does not provide a comprehensive and conclusive view of what these fundamental factors are. Hence, there is no such thing as the true theoretical model to explain long-run real exchange rate movements.

This uncertainty is well reflected in the empirical work regarding real exchange rates, as different studies can select different driving factors as potential

a The authors are very grateful to Bruno Parnisari and Peter Steiner (SECO) for supplying previously unavailable data on Swiss sectoral value added, as well as to Gian Maria Milesi Feretti (IMF) for placing his international data set on net foreign assets at our disposal and Richard McKenzie (OECD) for valuable data suggestions. We also wish to thank Thomas Moser, Ulrich Kohli, Michel Peytrignet, Luca Ricci as well as participants to SNB internal seminars for helpful discussions. Finally we thank two anonymous referees: the paper has taken substantial advantage of their comments. The opinions expressed in this paper are solely those of the authors and do not necessarily reflect the view of their affiliated organisations.

b Money and Capital Markets Department, International Monetary Fund, Washington DC. tmancinigriffoli@imf.org

c Foreign Exchange and Gold Unit, Swiss National Bank, Zurich. christoph.meyer@snb.ch

d Research Department, International Monetary Fund, Washington DC. jnatal@imf.org

e Economic Analysis Unit, Swiss National Bank, Zurich. attilio.zanetti@snb.ch 
explanatory variables for real exchange rate movements (see, for example, IMF (2006), IMF (2013) and Bussiere et al. (2010) for an extensive methodological discussion). Moreover, for any given theoretical driver, one can think of several empirical measures or proxies that might capture the corresponding effect.

In this paper, we refer to some of the theoretical arguments that have been proposed in the literature (Balassa, 1964; Samuelson, 1964; Dornbush, 1980; Neary, 1988; De Gregorio, Giovannini and Holger, 1994; Bergstrand, 1991; Ostry, 1994) to select a group of variables for an empirical investigation of Swiss real exchange rate developments. As for other studies, the choice of variables is somewhat arbitrary. The paper must thus be considered as one contribution among others to try and explain the exchange rate patterns of the Swiss franc (see also Lenz and SAVioz (2009), Reynard (2008)). In a companion paper, AdLer and Grisse (2014) extend our approach to a much larger - and yet still not exhaustive - number of explanatory variables and show how substantial the uncertainty surrounding this kind of model estimate is.

One of the specific contributions of our work is the effort made to improve data quality and availability. Some of the time series we use - specifically for Swiss sectoral value added and labour productivity - were created for this research project.

Our results point to relative government spending and relative terms of trade as the main drivers of the Swiss franc RER in the long run. GDP per capita and net foreign assets play a significant role, but only when including the JPY/CHF real exchange rate in the panel. No significant role seems to be played by Balassa-Samuelson effects.

The paper is structured as follows. Section 2 provides an overview of the theory on the real exchange rate determinants that we will then consider for our empirical analysis. In section 3, we introduce the relevant time series and describe the stylised facts. Particular focus is set on the (relative) productivity patterns, for two main reasons. First, because Balassa-Samuelson-related hypotheses often take centre stage in the real exchange rate debate. Second, because in the recent past reforms have been implemented that were aimed at strengthening Swiss productivity growth. Section 4 evaluates the stationarity properties of the series and describes the econometric methodology. Results are discussed in section 5 while section 6 concludes. 


\section{Determinants of the Real Exchange Rate: The Theory}

When talking about real exchange rate developments, the departure point is generally provided by the purchasing power parity (PPP) theory. In standard textbooks, in fact, long-run real exchange rate developments are generally considered to respond to the PPP theory. The absolute PPP principle states that the domestic price of a given basket of goods is equal across countries when converted into the same currency. The PPP principle is an extension of the Law of One Price, which holds that - when expressed in a common currency - the price of any international traded good should be identical anywhere in the world. Otherwise prices should converge due to arbitrage.

The shortcomings of this theory are readily apparent. First, PPP applies to tradable goods; accordingly, it is not relevant for goods and services which cannot be traded across countries. An increase in housing rents, for example, which would lift the Swiss CPI, cannot be expected to be matched by a depreciation of the Swiss nominal exchange rate. PPP is more appropriate when limited to producer price indices, which are based on prices of manufactured tradable goods. Indeed, TAYLOR and TAYLOR (2004) show that the long-run correlation between US and UK price levels expressed in dollars is significantly stronger when prices are measured with PPIs than with CPIs.

Second, even when considering producer price indices, some factors - such as transaction costs or simply the difficulty of defining identical and equally weighted baskets of goods across countries - can hinder a complete convergence of price levels across countries. For this reason, economists often refer to a less stringent formulation of the PPP theory: the relative PPP principle. The latter states that the differential in price level changes (i.e. inflation differentials) should be matched by equivalent movements in the nominal exchange rate, independently of gaps in the relative price levels.

In both its absolute and relative formulations, the PPP theory suggests that if one country's price level rises relative to another's, the currency of the first country will depreciate in nominal terms, so that the real exchange rate remains fixed.

However, empirical evidence suggests that real exchange rates do not remain fixed. To explain long-run drifts in CPI-based real exchange rates, economic theory emphasizes the distinction between the tradables and non-tradables components of the consumption basket. Since it is usually admitted that PPP holds for traded goods, long-run trends in the real exchange rate have to come from relative changes in non-tradable goods prices. In the next paragraphs, we review various explanations offered by the literature to understand long-run drifts in 
the CPI-based real exchange rate and separate them into two categories: supplyside factors and demand-side factors.

The number of potential explanatory factors is actually much larger (IMF 2013). Degrees-of-freedom motives impose a choice. Any such choice - including ours - is somewhat arbitrary by definition.

\subsection{Supply Side: The Balassa-Samuelson Effect}

The Balassa-Samuelson (hereafter BS) theory supposes that within each country labour is mobile intersectorally (but not internationally) and that capital is perfectly mobile internationally (Balassa, 1964; Samuelson, 1964). Hence, for any given country, the labour supply is given and cannot be extended. BS also postulate that in all countries productivity gains will tend to be larger in the highly competitive tradables sector than in the domestic non-tradables sector. Due to the existence of binding national constraints on the labour supply, higher productivity in tradables lifts real wages not only in the tradables sector but also in the non-tradables sector. As higher real wages in the non-tradables sector are not matched by equivalent productivity gains, production costs will push up prices.

As a consequence, if country A experiences a stronger labour productivity growth differential between tradables and non-tradables than country $\mathrm{B}$, country A's non-tradable goods prices will tend to rise faster than country B's and this will lead to a long-run appreciation of country A's real exchange rate. ${ }^{1}$

\subsection{Demand Side}

For a number of reasons, it is sensible to assume that the supply of non-tradable goods and services is generally less elastic than the supply of tradables. As a consequence, any shock that increases the relative demand for non-tradables is therefore likely to induce an increase in their relative price. In what follows we revise the main mechanisms identified in the literature.

1 Following the empirical literature, we measure our BS variables using relative mean labour productivity. One should, however, bear in mind that this choice implies a double short cut. First, the BS effect is best measured using total factor productivity growth, as relative labour productivity measures can be influenced by varying forms of capital deepening across industries. Unfortunately, TFP measures are very hard to obtain, particularly at a disaggregated level. Second, marginal productivity drives wage developments. Mean labour productivity equals marginal labour productivity only under the assumption that the economy is correctly proxied by a Cobb-Douglas production function. 


\subsubsection{Net Foreign Assets}

The first argument stresses the role of net foreign assets (NFA). The presumption is that in the long run, countries will be bound by their intertemporal budget constraints. Lenders will demand repayment of their loans and borrowers will have to reimburse their debts. This will require that lenders (borrowers) eventually run current account deficits (surpluses) to build down (build up) their net foreign asset holdings.

One important mechanism behind this rebalancing process is the idea that an increase in country A's NFA position could be seen as a net increase in wealth by country A consumers. Ceteris paribus, this increase in wealth will eventually give rise to an increase in country A's demand for both tradable and non-tradable goods. As non-tradable goods can only be produced domestically, their relative price will rise and the intertemporal adjustment mechanism will thus imply both a rise in the relative price of non-tradable goods (a real exchange rate appreciation) and a current account correction. ${ }^{2}$

Thus, countries with large, positive NFA will tend to have appreciating real exchange rates and vice versa for countries with negative NFA. Indeed, in their broad cross-country analysis, LANe and Milesi-Feretti (2002) find evidence that large positive NFA tend to be positively correlated with appreciating real exchange rates.

\subsubsection{Terms of Trade}

Terms of trade (TOT) changes are generally thought to affect the equilibrium level of the real exchange rate because of their effect on the demand ${ }^{3}$ for nontradables. Terms of trade are defined as the ratio of export to import prices (see appendix D), such that an improvement in the terms of trade leads to an

2 Mechanically, current account deficits should arise as the consequence of three complementary effects. First, the increase in consumption of both non-tradables and tradables leads to more imports. Second, given the supply constraints on non-tradables their relative price will increase, favouring a shift of the consumption basket towards tradables. Third, the increase in the relative price of non-tradables will tend to stimulate the production of non-tradables, at the expense of the production of tradables as productive resources are shifted from one sector to the other. This will of course accentuate the trade deficit for a given demand for tradables.

3 We include terms of trade changes among the demand-side determinants of the real exchange rate. Part of the literature, however, would consider terms of trade changes as pertaining to the supply-side determinant. If it is assumed that trade takes place in intermediate products, as inputs to the production of final goods, an improvement in the terms of trade, because it allows more to be produced with less, will be akin to an increase in productivity (КоHLI, 2004). 
increase in national income as exports become dearer and imports cheaper. As consumers' income increases, they are likely to increase spending on tradables and non-tradables alike. While tradables can be supplied freely on international markets at a given price (for a small open economy), non-tradable goods can only be produced domestically. An increase in demand for non-tradables thus leads to an upward shift in their relative price. Also, an increase in income may lead to a shift in consumers' preferences towards domestic non-tradable superior products, such as housing, health care, leisure-related services, education and culture.

If this terms-of-trade effect is more pronounced in country A than in country B, country A's currency will appreciate in real terms. The importance of TOT for real exchange rate developments is stressed by, among others, Dornbush (1980) and Neary (1988).

\subsubsection{Output per Capita}

Output per capita ( $\mathrm{Y}$ in our notation), aims at capturing income effects which might appreciate a country's currency. Here again, the link is two-fold: operating through higher demand for supply-constrained non-tradables, as well as through a preference shift in favour of non-tradables (BERGSTRAND, 1991). Theory would thus predict a positive sign on the coefficient of output per capita in a real exchange rate regression.

\subsubsection{Government Consumption}

The size of government consumption (as a share of GDP) is also one of the factors that can impact on the equilibrium real exchange rate. Higher government spending, in fact, is likely to lead to a public-sector-induced preference shift of final domestic demand in favour of domestic non-tradables, thereby raising their relative price (De Gregorio, Giovannini and Holger, 1994; Ostry, 1994).

\section{Determinants of the Real Exchange Rate: The Stylised Facts}

Before we proceed to formal regression analysis, we conduct a graphical investigation of the main developments experienced by these variables. Note that, throughout this work, we adopt the convention that an increase in the exchange rate time series corresponds to an appreciation.

Our database consists of yearly data from 1970 to 2011. Data cover 18 countries: 12 euro area countries (Austria, Belgium, Germany, Spain, Finland, France, 
Greece, Ireland, Italy, Netherlands, Luxembourg and Portugal), 3 EU but noneuro area countries (UK, Denmark, Sweden), as well as the US, Japan and Switzerland. Details regarding the series we used are provided in Appendix D.

One of the important innovations of this paper is to base results on direct measures of productivity by sector. ${ }^{4}$ For Switzerland, sectorial value added since 1970 was estimated at SECO, specifically for this study. It is used in this paper for the first time. Data on hours worked by sector were calculated by the authors.

\subsection{Balassa-Samuelson Measures}

We begin by looking at the variables which matter from the perspective of the Balassa-Samuelson argument. Following the standard procedure, we define a tradable and a non-tradable sector for Switzerland and its main trading partners. For all countries, the tradable sector is defined as industry (manufacturing, energy and water production). The non-tradable sector groups four distinct economic sectors: the construction sector, the trade sector (wholesale and retail trade, hotels and restaurants, transports and communication) a broadly defined financial sector (financial intermediation, insurances, real estate) and the public sector (public administration, teaching, health care and social services). ${ }^{5}$

\subsubsection{Swiss Labour Productivity}

Before we investigate relative productivity developments and their comovements with the real exchange rate, it is worth looking at the Swiss series in more detail. In this section, we propose an overview of the main trends in sectorial productivity.

Figure 1 shows the sectorial labour productivity time series, as obtained after dividing value added by the number of hours worked. Table 1 provides figures on average labour productivity growth in the various decades. Over the whole sample, productivity growth was strongest in industry. Between 1970 and 2011, this sector recorded average yearly productivity gains of $2.3 \%$. Up to 1991, the trade sector followed a very similar trend, which then flattened out till the late 1990s. Over the whole 1970-2011 period the trade sector nevertheless recorded

4 See Reynard (2008) for an alternative approach relying on a price ratio as a proxy for the relative productivity ratio at the core of the Balassa-Samuelson effect.

5 Our classification in tradable and non-tradable sectors is a quite standard one. This being said, it is obviously a simplification of the reality. To some extent, the banking, insurance or even the retail industries are certainly part of the tradable sector whereas the production of water should most likely be assigned to the non-tradable sector. 
Figure 1: Labour Productivity per Sector

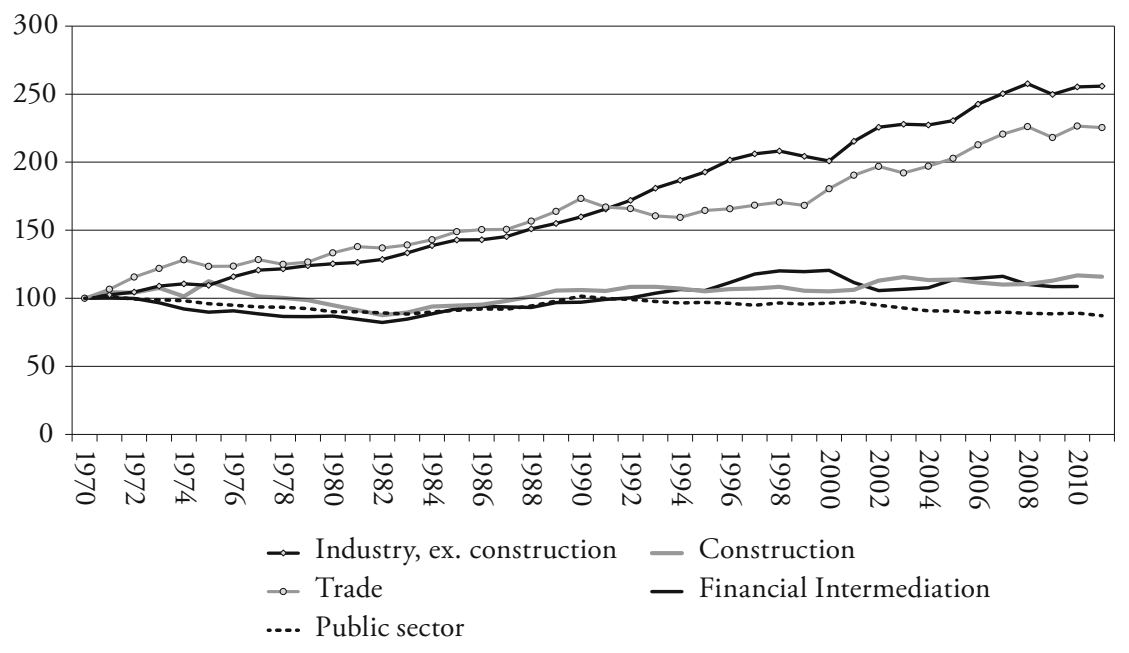

Table 1: Labour Productivity Growth in Switzerland

\begin{tabular}{l|rrrrrc|c}
\hline & \multicolumn{5}{|c|}{ Average } & St. dev. \\
& $1970-79$ & $1980-89$ & $1990-99$ & $2000-11$ & $1970-2011$ & $1970-2011$ \\
\hline Industry & 2.44 & 2.26 & 2.82 & 1.93 & 2.34 & 2.14 \\
Construction & -0.03 & 0.75 & 0.00 & 0.81 & 0.41 & 3.30 \\
Trade & 2.74 & 2.62 & 0.30 & 2.51 & 2.05 & 3.15 \\
Financial & -1.58 & 1.17 & 2.15 & -0.88 & 0.21 & 3.01 \\
Public & -0.86 & 0.60 & -0.21 & -0.76 & -0.32 & 1.54 \\
Total non-tradable & 0.81 & 1.42 & 0.98 & 0.36 & 0.87 & 1.57 \\
\hline
\end{tabular}

much larger productivity gains than the other non-tradable sectors. Indeed, productivity gains were positive overall but weak in the financial and construction sectors and negative in the public sector.

The globally weak growth performance of the Swiss economy in the 1990s gave rise to an intense political debate which motivated authorities to launch a comprehensive growth strategy in 2004 (see BrunetTI, 2004). Several measures were aimed at fostering labour productivity growth. ${ }^{6}$ As Table 1 shows,

6 See Brunetti (2004) for more details. 
our data point to a sharp acceleration in productivity growth in the trade sector in the 2000s compared to the previous decade. There are, however, no signs of enhanced productivity growth elsewhere. BRUNETTI (2008) comes to the same conclusion, suggesting that more time might be needed for structural changes to display their effect in terms of stronger productivity growth.

\subsubsection{Swiss Productivity Relative to the Rest of the World}

In this section, we will look at comovements between the BS relative productivity variables and the corresponding exchange rates. The relative productivities of tradables and non-tradables for Switzerland with respect to the US and euro area are illustrated in Figure 2. ${ }^{7}$ Details on productivity by country in tradables and non-tradables are presented in Table 2.

The top left graph of Figure 2 highlights that productivity growth in the tradable sector has been significantly stronger in the euro area than in Switzerland, although the trend has flattened out considerably since 1990.

A different picture emerges from the top-right graph. On average, over the whole period, productivity growth in the tradables sector has been relatively even between the US and Switzerland. Large swings can, however, be observed. Overall, between 1975 and 1996, Switzerland's tradables productivity grew considerably faster. These developments were largely offset by a period of faster productivity gains in the US between 1997 and 2004.

The two middle graphs of Figure 2 show the development of relative productivity for the non-tradables sector. Here again, euro area non-tradables productivity grew considerably faster than Switzerland's until the early 1980s. Thereafter the trend was partly reversed. With respect to the US, the graph displays large and persistent swings. At the end of our sample, however, Swiss productivity in nontradables relative to the US was at the same level as in 1970.

The two graphs in the lower row of Figure 2 show the BS measures, i.e. the ratio of tradables to non-tradables productivity between Switzerland and the foreign country. With respect to the euro area, the graph displays significant fluctuations around a downward trend. With respect to the US, the BS measure recorded a very substantial increase between the early 1970s and 1983. After this date, the measure trended downwards till 2000, before picking up again.

7 Only growth rates and the relative development of the various indices over time are relevant. According to the BS theory, it is in fact the differentials in productivity growth, and not productivity levels, that are responsible for real exchange rate movements. 
Figure 2: Swiss Relative Productivities of Tradables and Non-Tradables

Swiss/EMU tradables productivity $(1970=1)$

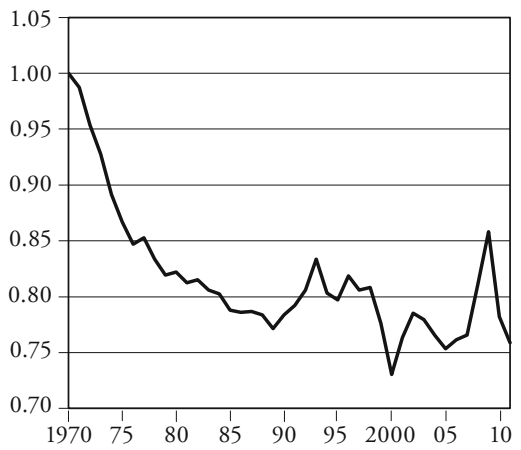

Swiss/EMU non tradables productivity $(1970=1)$

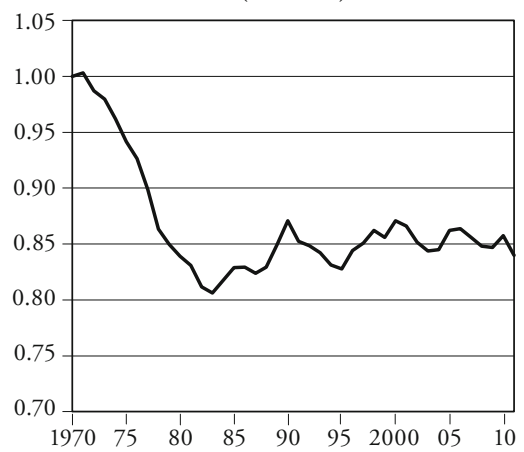

Swiss/EMU Balassa-Samuelson measure

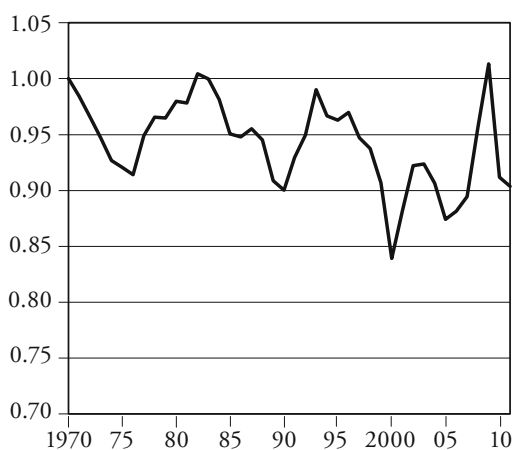

Swiss/US tradables productivity $(1970=1)$

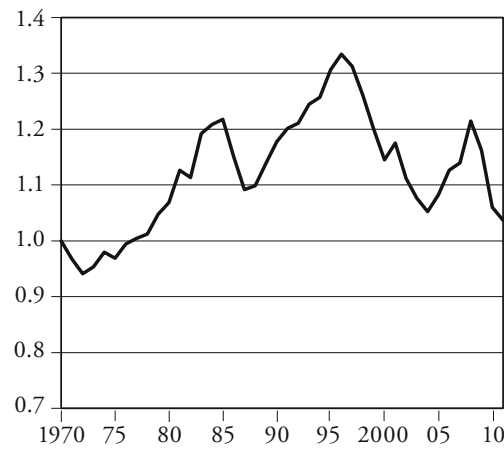

Swiss/US non tradables productivity $(1970=1)$

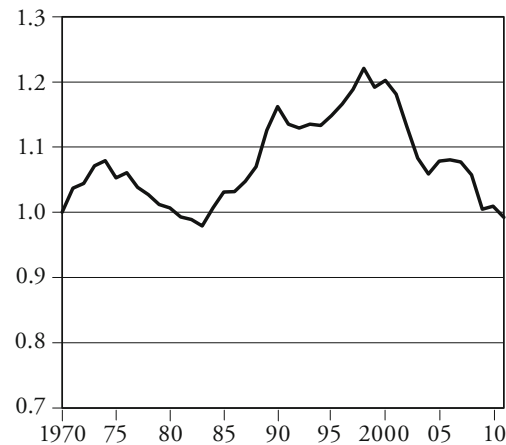

Swiss/US Balassa-Samuelson measure

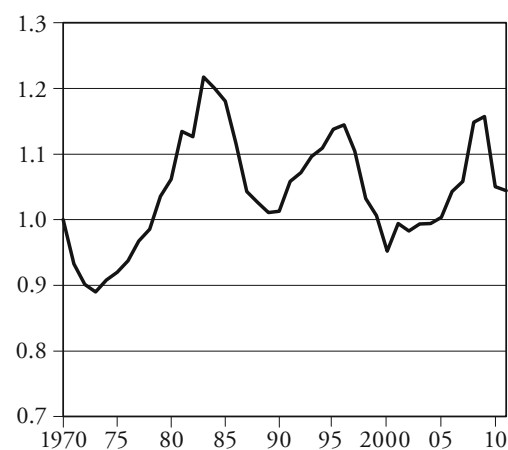


Table 2: Labour Productivity Growth, Tradables vs Non-Tradables

\begin{tabular}{|c|c|c|c|c|c|}
\hline & 1970-79 & 1980-89 & 1990-99 & $2000-11$ & 1970-2011 \\
\hline \multicolumn{6}{|l|}{ Switzerland } \\
\hline tradables & 2.44 & 2.26 & 2.82 & 1.93 & 2.34 \\
\hline nontradables & 0.81 & 1.42 & 0.98 & 0.36 & 0.87 \\
\hline \multicolumn{6}{|l|}{ Euro area } \\
\hline tradables & 4.73 & 2.89 & 2.75 & 2.18 & 3.05 \\
\hline nontradables & 2.65 & 1.42 & 0.89 & 0.51 & 1.29 \\
\hline \multicolumn{6}{|l|}{ UK } \\
\hline tradables & 2.28 & 3.75 & 3.35 & 2.06 & 2.84 \\
\hline nontradables & 0.64 & 1.06 & 1.87 & 0.93 & 1.13 \\
\hline \multicolumn{6}{|l|}{ Sweden } \\
\hline tradables & 6.66 & 2.92 & 2.47 & 1.87 & 3.33 \\
\hline nontradables & 2.34 & 1.45 & 1.22 & 0.86 & 1.42 \\
\hline \multicolumn{6}{|l|}{ Denmark } \\
\hline tradables & 2.45 & 2.94 & 3.47 & 3.60 & 3.15 \\
\hline nontradables & 0.94 & 0.89 & 1.12 & 0.93 & 0.97 \\
\hline \multicolumn{6}{|l|}{ USA } \\
\hline tradables & 1.93 & 1.47 & 2.28 & 3.22 & 2.28 \\
\hline nontradables & 0.67 & 0.34 & 0.40 & 1.90 & 0.88 \\
\hline \multicolumn{6}{|l|}{ Japan } \\
\hline tradables & 5.22 & 3.33 & 2.56 & 2.59 & 3.34 \\
\hline nontradables & 1.30 & 1.93 & 0.79 & 1.08 & 1.26 \\
\hline
\end{tabular}

Theory associates downward trends in the BS measure with a depreciation of the real exchange rate and upward trends with an appreciation. Figure 3 plots our BS measures against the corresponding bilateral real exchange rate of the CHF. On the whole, the negative trend in the BS measure does not square with the appreciating trend of the Swiss franc against the euro. Over shorter time periods, however, a somewhat stronger positive correlation may be discerned - between 1977 and 1982 or after 1990, for instance. With respect to the dollar, the patterns of the BS measure and of the real exchange rate seem to be more in line with each another, although the correlation is far from perfect. Between 1979 and 1987, for instance, we observe a strong negative correlation. 
Figure 3: Swiss BS Measures and Real Exchange Rates
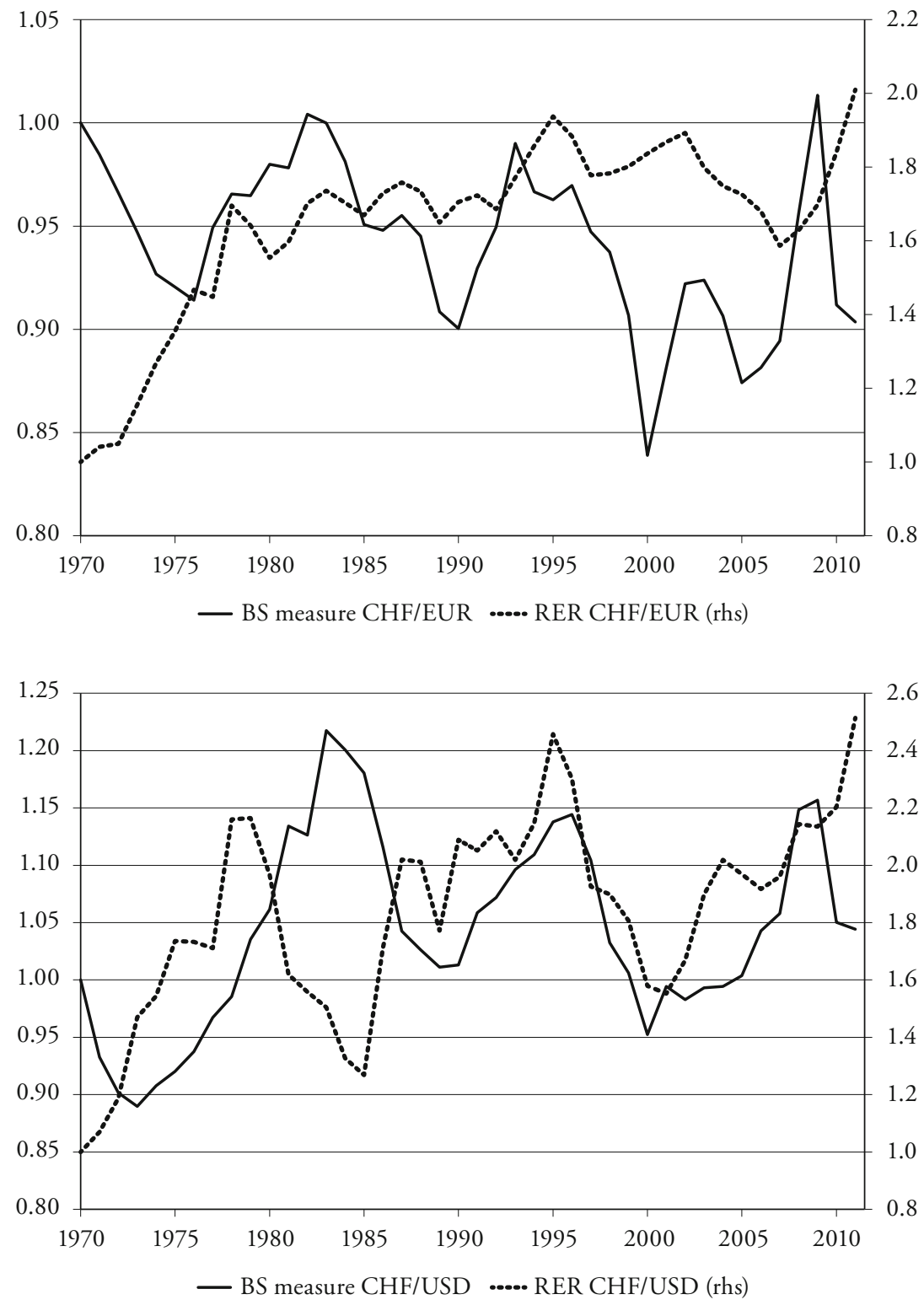
So far, we have looked only at data regarding the two main foreign currencies, EUR and USD. Our dataset also includes Japan, the UK, Denmark and Sweden. Figure 6 compares the effective BS measure with the real effective exchange rate. For all our variables, effective measures are obtained by computing a weighted average across all countries included in our dataset. Weights are equivalent to the share of each country in Swiss goods exports. The effective BS measure, for example, is computed as the Swiss productivity gap of the tradables versus the non-tradables sector, relative to the corresponding trade-weighted measure for the other countries (see Appendix D for details).

Figure 4: Swiss Effective BS Measure and the Real Effective Exchange Rate

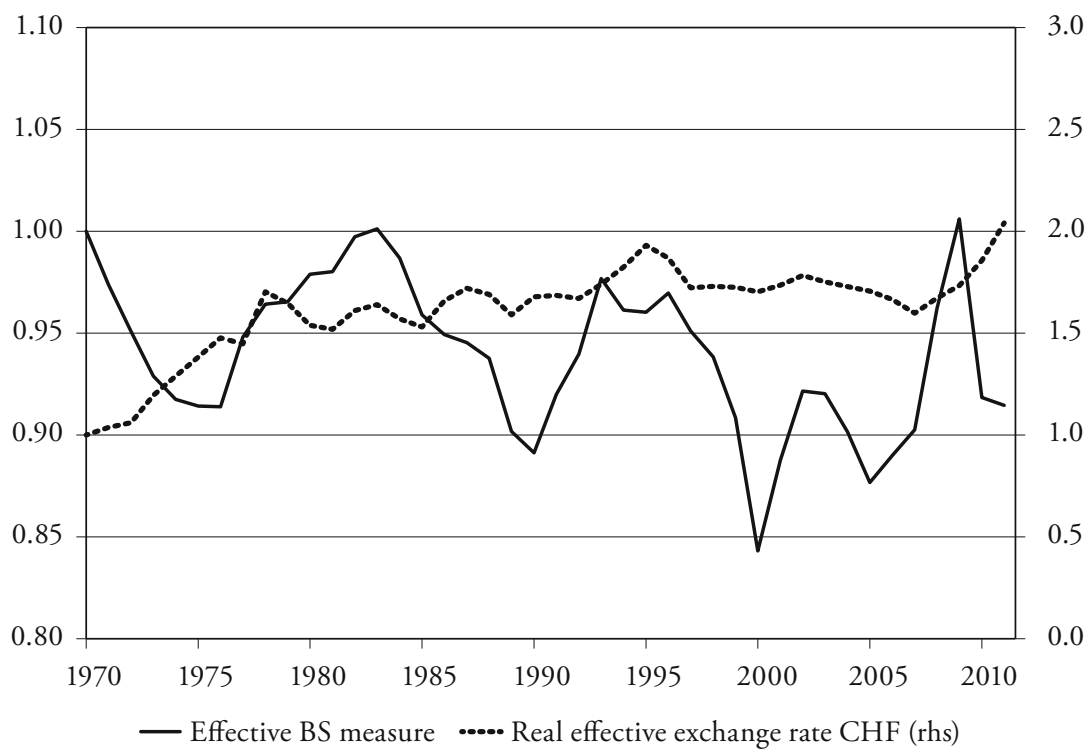

Figure 4 shows that the real effective exchange rate of the CHF appreciated between 1970 and the mid-1990s and again after 2007. The real effective exchange rate and the effective BS measure diverge over the long run. Although at times a positive short-run correlation can be observed, the fact remains that the fundamental message of the BS measure stands in contradiction to the observed development of the real effective exchange rate. 


\subsection{Other Variables}

We now examine the variables intended to measure demand-side factors. All variables are expressed in effective terms.

The upper-left graph of Figure 5 presents the relative development of Swiss net foreign assets. We control for the country size by measuring NFA as a percentage of GDP. In addition, in order to allow NFA to influence the bilateral real exchange rates, we need to know how Swiss NFA have evolved relative to the NFA of Switzerland's trading partners. We thus use Swiss NFA with respect to the rest of the world, relative to the NFA of all other individual countries with respect to the rest of the world. As Figure 5 shows, Swiss NFA have risen with respect to those of our trading partners. Their relative increase appears to have intensified since the mid-1990s.

Terms of trade move in the same direction. As one can see in the lower-left graph of Figure 5, they improved substantially over our sample period. The correlation, however, is not perfect. While the Swiss relative terms of trade developed almost as an exact mirror image of the real effective exchange rate until the mid1990s, they stagnated thereafter while the real effective exchange rate depreciated.

In any case, both these variables point to a very significant improvement of the relative wealth position of Switzerland and should therefore have contributed to the appreciation trend of the real effective exchange rate.

Our third measure provides the opposite picture. In terms of GDP per capita, the relative position of Switzerland has deteriorated significantly over time. While in the early 1970s Swiss relative GDP per capita was on average about $70 \%$ higher than in the other countries, the Swiss advantage declined continuously till 2004. It increased again slightly thereafter. In 2006, Swiss GDP per capita was only about $10 \%$ higher than in the other countries. This development clearly speaks for a trend depreciation of the Swiss real effective exchange rate.

Contrary to the other variables of Figure 5, the pattern of Swiss relative government consumption (as a percentage of GDP) displays very substantial swings. It first declined between 1970 and the early 1980s. It was then on the rise until the mid-1990s. This was the result of rising government consumption in Switzerland (although starting from an internationally low level) and efforts to stabilise (euro area) or reduce (in the US and the UK in particular) government spending elsewhere. After the turn of the century roles were swapped. Government spending growth was slowed in Switzerland thanks to the introduction of the debt-brake rule whereas several countries, initially the US, the UK and Japan and later continental Europe, experienced increases in government consumption as a share of GDP. 
Figure 5: Other Swiss Effective Measures

Effective relative net foreign assets

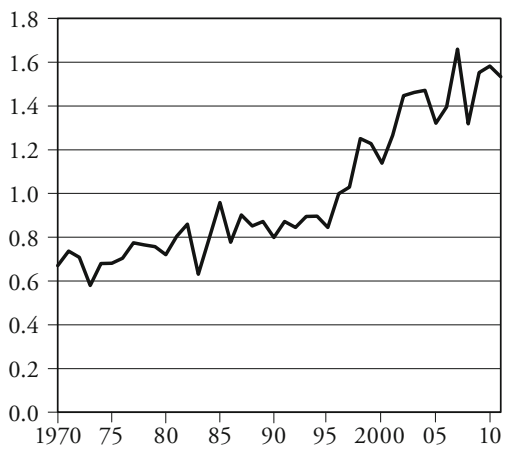

Effective relative terms of trade

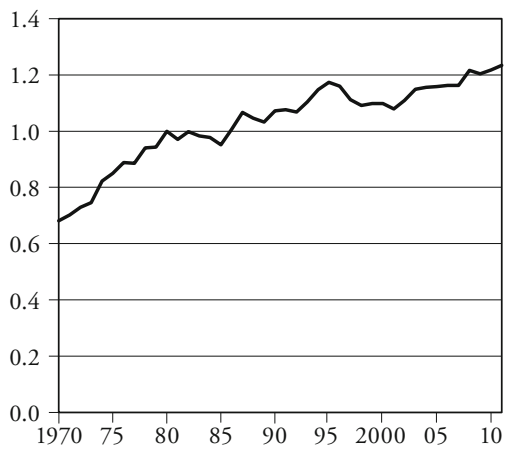

Effective relative GDP/capita

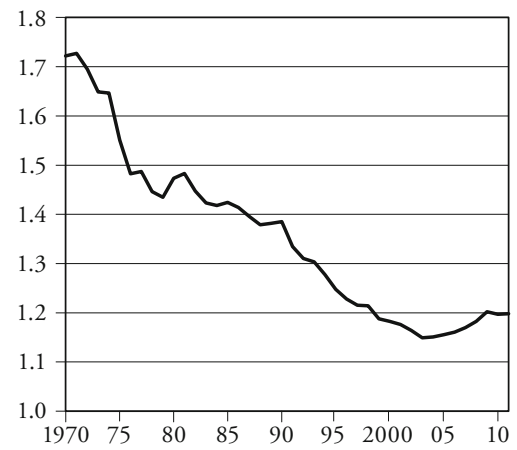

Effective relative government consumption

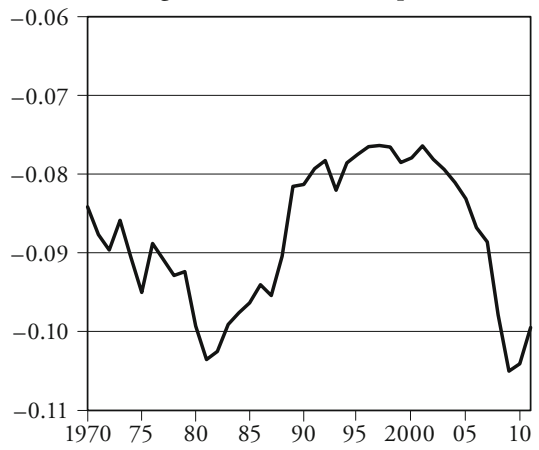

\section{Time Series Properties and Estimation Methodology}

As mentioned earlier, all our analysis focuses on the standard CPI-based real exchange rate, defined as

$$
R E R_{i t} \equiv \frac{C P I_{t} \cdot S_{i t}}{C P I_{t}^{*}},
$$

where $C P I_{t}$ is the domestic price level and $C P I_{t}^{*}$ the foreign one. $S_{i t}$ is the nominal exchange rate between the two countries, expressed in terms of country i's currency per unit of domestic currency. Hence, an increase in $R E R_{i t}$ corresponds 
to an appreciation. In all countries, the total CPI can be seen as a weighted average of the tradable $\left(P_{t}^{T}\right)$ and non-tradable $\left(P_{t}^{N T}\right)$ price level:

$$
C P I_{t}=\left(P_{t}^{T}\right)^{\alpha}\left(P_{t}^{N T}\right)^{1-\alpha},
$$

where $\alpha$ is the share of tradables in consumption. Accordingly, the CPI-based real exchange rate against any country $i, R E R_{i t}$, can be equivalently rewritten as the product of the relative price of tradable goods and the relative price of non-tradables: ${ }^{8}$

$$
R E R_{i t} \equiv \frac{C P I \cdot S_{i t}}{C P I^{*}}=\frac{\left(P_{C H, t}^{T}\right)^{\alpha}\left(P_{C, t}^{N T}\right)^{1-\alpha} S_{i t}}{\left(P_{i t}^{T}\right)^{\alpha}\left(P_{i t}^{N T}\right)^{1-\alpha}} .
$$

Taking logs and rearranging the above equation, we end up with an equivalent expression known as the ENGEL (1999) decomposition.?

$$
r e r_{i t}=\left[s_{i t}+p_{C H, t}^{T}-p_{i, t}^{T}\right]+(1-\alpha)\left[\left(p_{C H, t}^{N T}-p_{C H, t}^{T}\right)-\left(p_{i, t}^{N T}-p_{i, t}^{T}\right)\right],
$$

where small caps denote logarithms of variables. The preceding equation shows clearly that the real exchange rate is driven by two elements: the real exchange rate expressed in terms of tradables only - the first bracket - and the relative price of non-tradables over tradables across countries - the second bracket. In the long run, we expect PPP in tradables to hold, at least in relative terms, so that the equilibrium value of the expression in the first bracket should be a constant. This means that any long-run trend (stochastic or deterministic) in the real exchange rate must be explained by long-run trends in the relative price of non-tradables across countries. In what follows, we investigate the stochastic properties of CPI and PPI real exchange rates.

\subsection{Testing for PPP in Tradables}

Before running regressions of the real exchange rate on factors influencing the relative price of non-tradables - the second bracket in equation (4) - we must prove that we can ignore movements in the relative price of tradables in the long run - the first bracket - implying that PPP holds for tradable goods. To do so, we

8 We assume $\alpha=\alpha^{*}$.

9 See Appendix B for the derivation. 
performed various stationarity tests on the PPI real exchange rate, a very common proxy for the real exchange rate for tradable goods. The following table shows that running augmented Dickey-Fuller (ADF) tests on the whole data sample clearly rejects the assumption of a unit root for all relevant currency pairs. Furthermore, based on the complementary Kwiatkowski-Phillips-Schmidt-Shin (KPSS) tests, we could not reject the assumption of stationarity.

Table 3: Augmented Dickey-Fuller Unit Root Tests

\begin{tabular}{|lll|}
\hline $\begin{array}{l}\text { Variables: } \\
\text { Null hypothesis: } \\
\text { Sample: }\end{array}$ & \multicolumn{2}{l|}{$\begin{array}{l}\text { PPI-RER, CPI-RER has a unit root } \\
\text { 1970-2011 }\end{array}$} \\
\hline \multicolumn{3}{|c|}{ ADF test statistic } \\
& PPI-RER & CPI-RER \\
\hline Euro & -3.957 & -2.766 \\
Dollar & -5.029 & -3.248 \\
Effective & -4.594 & -3.050 \\
\hline Critical value 5\% & -2.937 & -3.526 \\
\hline
\end{tabular}

Table 4: KPSS Stationarity Tests

\begin{tabular}{|lcc|}
\hline $\begin{array}{l}\text { Variables: } \\
\text { Null hypothesis: } \\
\text { Sample: }\end{array}$ & $\begin{array}{l}\text { PPI-RER, CPI-RER } \\
\text { Series is stationary } \\
\text { 1970-2011 }\end{array}$ \\
\hline & \multicolumn{2}{c|}{ KPSS test statistic } \\
& PPI-RER & CPI-RER \\
\hline Euro & 0.331 & 0.582 \\
Dollar & 0.105 & 0.493 \\
Effective & 0.250 & 0.642 \\
\hline Critical value 5\% & 0.463 & 0.463 \\
\hline
\end{tabular}

Similar tests were run on the CPI real exchange rate. We could not reject the hypothesis of unit root against the trend stationarity alternative but could reject the assumption of trend stationarity according to the KPSS tests. 
Summing up, our results show that the CPI real exchange rate follows a unit root process whereas the PPI real exchange rate is stationary. On the one hand, this tends to confirm our prior assumption regarding PPP holding in tradables over the long run. On the other hand, it suggests that our empirical approach should aim at forming a co-integrating vector including the CPI real exchange rate and its fundamental determinants; the latter being the source of the stochastic trends of the CPI-based real exchange rate.

\subsection{A Co-Integrating Approach to the Real Exchange Rate}

Since we are dealing with non-stationary time series, the co-integration approach is the most natural way to proceed. The estimation of co-integration relationships between the real exchange rate and the potential fundamental factors provides us with estimates of the magnitude and significance of the effect of each independent variable on long-term fluctuations of the real exchange rate.

We follow the JoHANSEN (1995) procedure to estimate long-run relations on co-integrated time series. We consider information from all six bilateral currency pairs simultaneously in a panel regression, following the dynamic ordinary least squares technique (DOLS). The panel regression imposes equal coefficients on explanatory variables across currency pairs. This restriction allows the panel approach to take advantage of the variations between currency pairs as well as across time to increase the information set.

We maintain variables in relative (Swiss to foreign) terms and estimate the following regression:

$$
R E R_{i t}=\alpha_{i}+\beta^{\prime} \hat{\mathbf{X}}_{i t}+\sum_{s=-p}^{p} \gamma^{\prime} \Delta \hat{\mathbf{X}}_{i, t+s}+\epsilon_{t}
$$

where $\hat{\mathbf{X}}_{i t}$ is the panel of explanatory variables, and where $p$ is set to 1 . Note that $R E R_{i t}$ and $\hat{\mathrm{X}}_{i t}$ are not individual countries but stacked cross-section time series variables including all available countries in the sample.

The lagged and lead terms enter as warranted by the DOLS estimation methodology. The OLS estimator exhibits a non-negligible bias with finite samples in panel co-integrated regression models. To correct for this KAO, CHIAng and Chen (1999) as well as Phillips and Moon (1999) suggest using the DOLS estimator, based on the single equation dynamic ordinary least squares method of Saikkonen (1991) and Stock and Watson (1993). Details on the DOLS estimator are given in Appendix C. 


\section{Empirical Results}

Our dataset covers the 1970-2011 period. For regression purposes, however, we decided to limit the sample to the period starting with the introduction of the flexible exchange rate regime. Hence, all co-integration tests and regressions use annual data for 1973 to 2011 .

\subsection{Testing for Co-Integration}

As shown in Johansen (1995) and Hamilton (1994), the vector representation of possibly co-integrated time series is a preferred approach to test for cointegration among variables. The max-eigenvalue and trace statistic tests for the number of linearly independent co-integration relationships in a six-variable VECM system, including all potential fundamental determinants of the equilibrium real exchange rate (TOT, BS, G, NFA, Y), tend to show that, at least, one co-integrating vector can be found in each bilateral country regression. Table 5, panel A through F, shows the results for our six exchange rate pairs in detail.

\subsection{Regressions}

Next we use our panel to run DOLS regressions. Again, the panel consists of six countries - Euro area, USA, UK, Japan, Sweden and Denmark - and all regressions use annual data for 1973 to $2011 .^{10}$

Table 6 presents the estimated coefficients of our regressions. Standard errors are in parenthesis.

Let us look at our baseline specification in the first regression column. Several general features stand out. First, and most importantly, all coefficients are positive, as suggested by theory. An increase in any one of these variables tends to produce an appreciation of the real exchange rate in the long run. Second, all variables but the Balassa-Samuelson measure are highly significant.

The largest coefficient is that of government consumption, followed by terms of trade and GDP per capita. The impact of net foreign assets is also significant

10 We tested for breaks in the real exchange rate series, using both recursive estimates of an AR(1) process as well as F-tests on average growth rates. None of the outcomes pointed to statistically significant breaks in our series. We therefore maintained the 1973-2011 sample period, which makes it possible to maximise the number of degrees of freedom in our regressions. 
Table 5: Unrestricted Cointegration Rank Tests (Sample: 1973-2011)

\begin{tabular}{|c|c|c|c|c|c|}
\hline \multicolumn{3}{|c|}{$\begin{array}{c}\text { Panel A } \\
\text { EUR/CHF Real Exchange Rate }\end{array}$} & \multicolumn{3}{|c|}{$\begin{array}{c}\text { Panel B } \\
\text { USD/CHF Real Exchange Rate }\end{array}$} \\
\hline \multicolumn{3}{|c|}{ Trace rest } & \multicolumn{3}{|c|}{ Trace rest } \\
\hline Hyp. No of CE & Trace stat & $5 \%$ crit. value & Hyp. No of CE & Trace stat & $5 \%$ crit. value \\
\hline $\begin{array}{l}\text { none** } \\
\text { at most } 1^{* *} \\
\text { at most } 2\end{array}$ & $\begin{array}{r}126.603 \\
73.897 \\
42.305\end{array}$ & $\begin{array}{l}95.754 \\
69.819 \\
47.856 \\
\end{array}$ & $\begin{array}{l}\text { none** } \\
\text { at most } 1 \\
\text { at most } 2\end{array}$ & $\begin{array}{r}100.650 \\
56.706 \\
34.115\end{array}$ & $\begin{array}{l}95.754 \\
69.819 \\
47.856 \\
\end{array}$ \\
\hline \multicolumn{3}{|c|}{ Maximum Eigenvalue test } & \multicolumn{3}{|c|}{ Maximum Eigenvalue test } \\
\hline Hyp. No of CE & Max- $\lambda$ stat. & $5 \%$ crit. value & Hyp. No of CE & Max- $\lambda$ stat. & $5 \%$ crit. value \\
\hline $\begin{array}{l}\text { none } \\
\text { at most } 1 \\
\text { at most } 2\end{array}$ & $\begin{array}{l}52.707 \\
31.592 \\
21.821 \\
\end{array}$ & $\begin{array}{l}40.078 \\
33.877 \\
27.584 \\
\end{array}$ & $\begin{array}{l}\text { none** } \\
\text { at most } 1 \\
\text { at most } 2\end{array}$ & $\begin{array}{l}43.944 \\
22.591 \\
14.249 \\
\end{array}$ & $\begin{array}{l}40.078 \\
33.877 \\
27.584 \\
\end{array}$ \\
\hline \multicolumn{3}{|c|}{$\begin{array}{c}\text { Panel C } \\
\text { JPY/CHF Real Exchange Rate }\end{array}$} & \multicolumn{3}{|c|}{$\begin{array}{c}\text { Panel D } \\
\text { GBP/CHF Real Exchange Rate }\end{array}$} \\
\hline \multicolumn{3}{|c|}{ Trace rest } & \multicolumn{3}{|c|}{ Trace rest } \\
\hline Hyp. No of CE & Trace stat & $5 \%$ crit. value & Hyp. No of CE & Trace stat & $5 \%$ crit. value \\
\hline $\begin{array}{l}\text { none** } \\
\text { at most } 1^{* *} \\
\text { at most } 2\end{array}$ & $\begin{array}{r}120.625 \\
80.543 \\
47.554\end{array}$ & $\begin{array}{l}95.754 \\
69.819 \\
47.856\end{array}$ & $\begin{array}{l}\text { none** } \\
\text { at most } 1 \\
\text { at most } 2\end{array}$ & $\begin{array}{r}116.901 \\
64.770 \\
35.865\end{array}$ & $\begin{array}{l}95.754 \\
69.819 \\
47.856\end{array}$ \\
\hline \multicolumn{3}{|c|}{ Maximum Eigenvalue test } & \multicolumn{3}{|c|}{ Maximum Eigenvalue test } \\
\hline Hyp. No of CE & Max- $\lambda$ stat. & $5 \%$ crit. value & Hyp. No of CE & Max- $\lambda$ stat. & $5 \%$ crit. value \\
\hline $\begin{array}{l}\text { none** } \\
\text { at most } 1 \\
\text { at most } 2\end{array}$ & $\begin{array}{l}40.082 \\
32.988 \\
23.985 \\
\end{array}$ & $\begin{array}{l}40.076 \\
33.877 \\
27.584 \\
\end{array}$ & $\begin{array}{l}\text { none** } \\
\text { at most } 1 \\
\text { at most } 2\end{array}$ & $\begin{array}{l}52.137 \\
28.905 \\
19.925 \\
\end{array}$ & $\begin{array}{l}40.078 \\
33.877 \\
27.584 \\
\end{array}$ \\
\hline \multicolumn{3}{|c|}{$\begin{array}{c}\text { Panel E } \\
\text { SEK/CHF Real Exchange Rate }\end{array}$} & \multicolumn{3}{|c|}{$\begin{array}{c}\text { Panel F } \\
\text { DKK/CHF Real Exchange Rate }\end{array}$} \\
\hline \multicolumn{3}{|c|}{ Trace rest } & \multicolumn{3}{|c|}{ Trace rest } \\
\hline Hyp. No of CE & Trace stat & $5 \%$ crit. value & Hyp. No of CE & Trace stat & $5 \%$ crit. value \\
\hline $\begin{array}{l}\text { none** } \\
\text { at most } 1 \\
\text { at most } 2\end{array}$ & $\begin{array}{r}108.682 \\
67.441 \\
39.548\end{array}$ & $\begin{array}{l}95.754 \\
69.819 \\
47.856\end{array}$ & $\begin{array}{l}\text { none** } \\
\text { at most } 1^{* *} \\
\text { at most } 2\end{array}$ & $\begin{array}{r}131.799 \\
84.028 \\
45.565\end{array}$ & $\begin{array}{l}95.754 \\
69.819 \\
47.856 \\
\end{array}$ \\
\hline \multicolumn{3}{|c|}{ Maximum Eigenvalue test } & \multicolumn{3}{|c|}{ Maximum Eigenvalue test } \\
\hline Hyp. No of CE & Max- $\lambda$ stat. & $5 \%$ crit. value & Hyp. No of CE & Max- $\lambda$ stat. & $5 \%$ crit. value \\
\hline $\begin{array}{l}\text { none } \\
\text { at most } 1 \\
\text { at most } 2\end{array}$ & $\begin{array}{l}41.240 \\
27.893 \\
18.460\end{array}$ & $\begin{array}{l}40.078 \\
33.877 \\
27.584\end{array}$ & $\begin{array}{l}\text { none** } \\
\text { at most } 1^{* *} \\
\text { at most } 2\end{array}$ & $\begin{array}{l}47.771 \\
38.462 \\
20.810\end{array}$ & $\begin{array}{l}40.076 \\
33.877 \\
27.584\end{array}$ \\
\hline
\end{tabular}

** denotes rejection of the hypothesis at the $5 \%$ level 
Table 6: Regression Results: DOLS with Six Countries

\begin{tabular}{|c|c|c|c|c|c|c|}
\hline & \multicolumn{6}{|c|}{ Dep. variable: real exchange rate (standard error in parenthesis) } \\
\hline & 1 & 2 & 3 & 4 & 5 & 6 \\
\hline & $\begin{array}{c}\text { DOLS } \\
5 \text { var. } \\
1973-2011\end{array}$ & $\begin{array}{c}\text { DOLS } \\
3 \text { var. } \\
1973-2011\end{array}$ & $\begin{array}{c}\text { DOLS } \\
\text { 5 var. } \\
1973-2007\end{array}$ & $\begin{array}{c}\text { DOLS } \\
3 \text { var. } \\
1973-2007\end{array}$ & $\begin{array}{c}\text { DOLS } \\
\text { 5 var. } \\
1973-2011\end{array}$ & $\begin{array}{c}\text { DOLS } \\
6 \text { var. } \\
1973-2007\end{array}$ \\
\hline BS & $\begin{array}{c}0.178 \\
(0.137)\end{array}$ & $\begin{array}{c}0.056 \\
(0.144)\end{array}$ & $\begin{array}{c}0.194 \\
(0.141)\end{array}$ & $\begin{array}{c}0.056 \\
(0.144)\end{array}$ & $\begin{array}{c}-0.053 \\
(0.165)\end{array}$ & $\begin{array}{c}-0.053 \\
(0.165)\end{array}$ \\
\hline G & $\begin{array}{l}1.736^{* * *} \\
(0.555)\end{array}$ & $\begin{array}{l}1.458^{* * *} \\
(0.495)\end{array}$ & $\begin{array}{l}1.857^{* * *} \\
(0.596)\end{array}$ & $\begin{array}{l}1.643^{* * *} \\
(0.532)\end{array}$ & $\begin{array}{l}1.615^{* *} \\
(0.689)\end{array}$ & $\begin{array}{l}2.119^{* * *} \\
(0.689)\end{array}$ \\
\hline TOT & $\begin{array}{l}0.578^{* * *} \\
(0.074)\end{array}$ & $\begin{array}{l}0.630^{* * *} \\
(0.065)\end{array}$ & $\begin{array}{l}0.602^{* * *} \\
(0.084)\end{array}$ & $\begin{array}{l}0.592^{* * *} \\
(0.071)\end{array}$ & & \\
\hline Y & $\begin{array}{l}0.478^{* * *} \\
(0.104)\end{array}$ & & $\begin{array}{l}0.552^{* * *} \\
(0.106)\end{array}$ & & $\begin{array}{l}0.306^{* *} \\
(0.120)\end{array}$ & $\begin{array}{l}0.366^{* * *} \\
(0.120)\end{array}$ \\
\hline NFA & $\begin{array}{l}0.282^{* * *} \\
(0.040)\end{array}$ & & $\begin{array}{l}0.285^{* * *} \\
(0.045)\end{array}$ & & $\begin{array}{l}0.284^{* * *} \\
(0.047)\end{array}$ & $\begin{array}{l}0.266^{* * *} \\
(0.052)\end{array}$ \\
\hline IV for TOT & & & & & $\begin{array}{l}0.426^{* * *} \\
(0.112)\end{array}$ & $\begin{array}{l}0.397^{* * *} \\
(0.131)\end{array}$ \\
\hline
\end{tabular}

at the $1 \%$ level but less marked. ${ }^{11}$ Contrary to what one might have expected, the Balassa-Samuelson (BS) relative productivities term is not significant at all. This might be due to the fact that a fundamental hypothesis in the BS mechanism is that the labour supply is binding. Given the traditionally strong immigration flows to Switzerland this assumption is not met.

A closer look at the data suggests that the results concerning NFA and Y are strongly driven by the importance of these variables for the JPY/CHF cross. ${ }^{12}$ We thus checked how the other estimated coefficients react once NFA and Y are excluded from the panel. Results can be found in the second column of Table 6 . The specification change does not modify the estimated coefficients for BS, G and TOT in any significant way.

In a further step we investigated whether the world-wide recession that was initiated by the US subprime crisis and the collapse of Lehman Brothers has

11 This result is supported by the work of Lane and Milesi-Ferretti (2002) who find that countries which have been accumulating current account surpluses tend to have appreciating currencies.

12 For a direct comparison, Table D6 in the appendix provides regression results based on a sample that excludes JPY/CHF and the related variables. 
impacted the empirical relation between our variables. In columns 3 and 4, Table 6 presents the results of our regressions for the period up to 2007. The estimated coefficients look very similar to the ones for the full sample. Hence, our results appear to be robust from this perspective.

Next we deal with the potential endogeneity problem raised by terms of trade. Theoretically the case for TOT to enter our regressions is clear. In practice, however, the inclusion of terms of trade in a regression of the real exchange rate might pose some problems. Nominal exchange rate developments influencing both the real exchange rate and the terms-of-trade variable, one could suspect that the significance of TOT in the regressions of Table 6 is essentially driven by this endogeneity mechanism. This mechanical link can bias the results in favour of terms of trade, or at least can give terms of trade excessive explanatory power over and above that intended to proxy for income effects.

A first barrier against this potential bias relies on the DOLS approach. HAYASHI (2000) as well as other authors show that least squares may be used to consistently estimate a normalised co-integrating vector. However, the asymptotic behaviour of the least squares estimator is nonstandard. The least squares estimate $\boldsymbol{\beta}$ is consistent for $\boldsymbol{\beta}$ and converges to $\boldsymbol{\beta}$ at rate $T$ instead of the usual rate square root of $T$. That is, $\boldsymbol{\beta}$ is super consistent. $\boldsymbol{\beta}$ is consistent even if the explanatory variable is correlated with the residuals, so that there is no asymptotic simultaneity bias. However, even though the asymptotic bias tends to zero as $T$ gets large $\boldsymbol{\beta}$ may indeed be substantially biased in small samples. The least squares estimator is also not efficient. As pointed out by the same author and by Sтоск and WATSON (1993), this problem disappears if the DOLS approach is adopted. The DOLS approach provides a simple way for obtaining an asymptotically efficient estimator for the normalised co-integrating vector $\boldsymbol{\beta}$ as well as a valid formula for computing its asymptotic variance. By augmenting the regression with $\mathrm{p}$ leads and lags of the independent variable's first differences and estimating the regression by least squares, an estimator of $\boldsymbol{\beta}$ is found - denoted $\boldsymbol{\beta}\{$ DOLS $\}$ - that is consistent, asymptotically normally distributed and efficient, i.e. equivalent to a maximum likelihood estimator.

In addition, to further investigate this issue we adopt an instrumental variable approach. We regress our TOT variable on the relevant bilateral nominal exchange rate and a constant. Then we take the residuals from this regression as our instrumental variable. This residual reflects all movements of the TOT that are uncorrelated with developments in the nominal exchange rate.

We replace the TOT by our instrumental variable (IV) in our baseline regression, both in the full sample and in the sample restricted to the pre-crisis period. Regressions 5 and 6 in Table 6 provide the results. The coefficient of our 
instrumental variable is somewhat smaller than that of TOT in regressions 1 to 4 , but it remains sizeable and very significant. Hence, the strong significance of TOT in our baseline regression cannot be attributed to the role of the nominal exchange rate.

Summing up, these results suggest that there is a strong link between the relative share of government consumption in GDP and the relative terms of trade, on the one hand, and the real exchange rate, on the other. The estimated Balassa-Samuelson coefficients bear the correct sign but are not statistically significant in our baseline specification. When using an instrumental variable instead of the TOT, the coefficient for BS even turns negative. In addition to these factors, net foreign assets and GDP per capita appear to exert a significant influence when the JPY/CHF real exchange rate is included. This shows the limits of empirical models in which the variable selection is not operated on the basis of a structural theoretical model. Adding or removing a country can strongly affect the significance of some explanatory variables. Similarly, adding other explanatory variables - demographic variables for example - may also have an important impact on other variables. AdLER and Grisse (2014) investigate this problem in detail. Following a similar panel approach to the one we adopted, they estimate a much larger number of models using various combinations from a larger set of explanatory variables and currencies over different sample periods. They then apply Bayesian averaging to assess the uncertainty of parameter estimates. Their results clearly show that empirical models like the one we estimated can do a good job in replicating the real-exchange-rate trends but that no 'true model' exists. Parameter estimates can vary substantially depending on the set of variables and currencies included in the regressions.

\subsection{Further Robustness Checks}

Several additional issues were investigated in order to further check for robustness. First, we substituted our GDP-per-capita variable with other measures of income, including GNI per capita. None of these alternative measures proved to be superior to our initial choice.

Second, we tested for misspecification. A dummy for the 1992-1995 period was included to capture specific shocks linked with the EMS turmoil. Additionally, in order to account for possible short-term effects of real money, we introduced a measure of the relative real money gaps (i.e. real M2 growth less real GDP growth). None of these variables turned out to be significant.

Finally, we compared our results with results from similar DOLS regressions conducted by the IMF (Lee, Milesi Ferretti and Ricci, 2008) using a very 
large balanced sample of 48 countries for 861 observations in total. The relevant figures are presented in Table 7. Our estimates for the TOT and BS coefficients are strikingly similar to the ones of LeE et al. (2008). For the G and NFA coefficients discrepancies arise. Given the purely empirical nature of this excercise - and thus the absence of theoretically founded benchmark values for the estimated coefficients - these differences do not appear to go beyond what one might reasonably expect.

Table 7: Robustness Check

\begin{tabular}{lcc}
\hline & \multicolumn{2}{c}{$\begin{array}{c}\text { Dep. variable: real exchange rate } \\
\text { (standard error in parenthesis) }\end{array}$} \\
& DOLS baseline & Lee et al. (2008) \\
\hline TOT & $\begin{array}{c}0.578^{* * *} \\
(0.074)\end{array}$ & $\begin{array}{c}0.60^{* * *} \\
(0.00)\end{array}$ \\
G & $1.736^{* * *}$ & $3.76^{* * *}$ \\
& $(0.555)$ & $(0.00)$ \\
BS & 0.178 & $0.24^{* *}$ \\
& $(0.137)$ & $(0.03)$ \\
NFA & $0.282^{* * *}$ & $0.04^{* *}$ \\
& $(0.040)$ & $(0.00)$ \\
Y & $0.478^{* * *}$ & \\
& $(0.104)$ & \\
\hline
\end{tabular}

\section{Conclusions}

We conducted an empirical investigation of the real exchange rate determinants of the Swiss franc. The choice of potential explanatory factors was based on both standard theoretical arguments and recent international empirical evidence. In the process, an effort was made to improve the quality of the data as compared with the empirical investigation conducted so far on the Swiss franc exchange rate. Our annual dataset covers the 1973-2011 period.

Our results point to relative government spending and relative terms of trade as the main drivers of the Swiss franc RER in the long run. GDP per capita and net foreign assets play a significant role, but only when including the JPY/CHF real exchange rate in the panel. Contrary to what one might expect based on common wisdom, relative productivity differentials - i.e. the Balassa-Samuelson mechanisms - do not appear to play any statistically significant role. 
In spite of their robustness, our results should not be misinterpreted. No single true model exists to investigate real exchange rate developments. The issue with the JPY/CHF cross clearly shows that regression results are highly sensitive to the choice of the explanatory variables and exchange rate crosses included in the sample. Adler and Grisse (2014) provide formal evidence of the uncertainty surrounding these kinds of exchange-rate models. Our paper must thus be seen as one contribution in a much larger research programme to understand Swiss real exchange rate behaviour.

\section{Appendix}

\section{A. The Engel Decomposition}

Define the real exchange rate between Switzerland and country $i$ as:

$$
Q_{i t}=\frac{P_{C H, t}}{P_{i t} / S_{i t}}=\frac{S_{i t}\left(P_{C H, t}^{T}\right)^{\alpha_{C H, t}}\left(P_{C H, t}^{N T}\right)^{1-\alpha_{C H, t}}}{\left(P_{i t}^{T}\right)^{\alpha_{i t}}\left(P_{i t}^{N T}\right)^{1-\alpha_{i t}}}
$$

where $T$ denotes tradables and $N T$ non-tradables, and $S_{i t}$ is the nominal exchange rate between Switzerland and country i defined as units of foreign currency per unit of domestic currency, so that an increase in $S_{i t}$ is an appreciation of the domestic currency. Also, $\alpha_{s t}$ for $s \in\{i, C H\}$ are consumption weights on tradables in country $s$; the time subscript indicates that these are allowed to change in time.

We proceed by taking logs of the above variables which we correspondingly write in lower case such that $x=\ln (X)$ for any variable $X$. The definition of the real exchange rate therefore becomes:

$$
q_{i t}=\alpha_{C H, t} p_{C H, t}^{T}-\alpha_{i t} p_{i t}^{T}+s_{i t}+\left(1-\alpha_{C H, t}\right) p_{C H, t}^{N T}-\left(1-\alpha_{i t}\right) p_{i t}^{N T}
$$

Next, we add and subtract $\left(1-\alpha_{C H, t}\right) p_{C H, t}^{T}$ and $\left(1-\alpha_{i t}\right) p_{i t}^{T}$ from the right hand side, in order to obtain the Engel (1999) decomposition:

$$
q_{i t}=q_{i, T T}+\left(1-\alpha_{C H, t}\right)\left(p_{C H, t}^{N T}-p_{C H, t}^{T}\right)-\left(1-\alpha_{i t}\right)\left(p_{i t}^{N T}-p_{i t}^{T}\right)
$$

where $q_{i, T T} \equiv p_{C H, t}^{T}-p_{i t}^{T}+s_{i t}$, which is the relative price of tradables; we call this the "law of one price ratio" term. The next two terms in parentheses are the internal terms of trade for Switzerland and the foreign country $i$, respectively. 


\section{B. The DOLS Estimation Method}

It is easiest to begin with a basic triangular representation of a co-integrated system given by:

$$
\begin{aligned}
& y_{i t}=\alpha_{i}+\gamma^{\prime} x_{i t}+u_{i t} \\
& x_{i t}=x_{i, t-1}+v_{i t}
\end{aligned}
$$

where $\left(1-\gamma^{\prime}\right)$ is the co-integrating vector between $y_{i t}$ and $x_{i t}$, both of which are $\mathrm{I}(1)$, and the error $u_{i t}$ is independent across $i$ but possibly dependent across $t$. Note that both $x_{i t}$ and $y_{i t}$ are I(1). The setup yields two forms of bias. First, the serial correlation in the errors, and second the endogeneity of the regressors, due to the non-zero correlation between $u_{i t}$ and at most $p$ leads and lags of $v_{i t}$. To correct for endogeneity, project $u_{i t}$ onto the leads and lags of the $v_{i t}$ to yield:

$$
u_{i, t}=\sum_{j=-p}^{p} \delta^{\prime} \nu_{i, t+j}+\epsilon_{i, t}=\sum_{j=-p}^{p} \delta^{\prime \prime} x_{i, t+j}+\epsilon_{i, t}
$$

where $\epsilon_{i, t}$ is by construction orthogonal to the leads and lags of $v_{i, t}$.

Replacing this result in the regression equation yields:

$$
y_{i, t}=\alpha_{i}+\gamma^{\prime} x_{i, t}+\sum_{j=-p}^{p} \delta^{\prime \prime \prime} x_{i, t+j}+\epsilon_{i, t}
$$

which can be estimated by fixed effects, using OLS. Doing so is in fact applying the so-called DOLS estimator.

See Baltagi and Kao (2000) or Phillips and Moon (2000) for a survey, or HAYASHI (2000), Chapter 10, for a very clear explanation of the DOLS methodology and MARK and Sul (2003) for a more advanced discussion.

\section{Dataset}

Our database consists of yearly data from 1970 to 2011. It encompasses 18 countries: 12 euro area countries (Austria, Belgium, Germany, Spain, Finland, France, Greece, Ireland, Italy, Netherlands, Luxembourg and Portugal), three EU but non-euro area countries (UK, Denmark, Sweden), as well as the US, Japan and Switzerland. As far as possible, we drew series from single, standard sources, at times using other sources either to check the plausibility of data, or to extrapolate wherever observations were missing. 


\section{Value added data}

We used direct measures of productivities by sector. Five sectors are taken into account: industry (manufacturing, energy and water production) defines the tradables sector; construction, trade (trade, hotels and restaurants, transports and communication), the financial sector (financial intermediation, insurances, real estate) and the public sector (public administration, teaching, health care and social services) jointly define the non-tradables sector.

For most countries, we relied on a highly detailed database EU KLEMS (see www.euklems.net) developed at the University of Groningen for the European Commission. This database contains time series on labour productivity per hour worked at a disaggregated sectoral level for several European countries as well as for the US. The only relevant missing Swiss trade partner is Japan, for which we refer to productivity for unit of labour input as computed by the OECD. Where needed, time series where completed based on data stemming from the Haver database. For Switzerland, new time series on sectoral value added were estimated by SECO for this study.

\section{Hours worked}

Data on hours worked by sector in Europe and in the US are also available in the KLEMS database.

As far as Switzerland is concerned, these series were produced by the authors using different sources. For the 1991-2005 period, we used official SFSO data on the annual volume of hours worked. Figures for 2006 were extrapoleted using the growth rate of the full-time-equivalent employment statistics. For the period between 1970 and 1991, we proceeded in several steps. Hours worked were first retropolated using standard employment indexes developed by the SFSO. In order to take the decline in the annual number of hours worked per person into due account, we used the 1980 official population survey as well as the Historical statistics of Switzerland to extract information on average hours worked in the 1970s and 1980s. In addition, we used information from ANDRIST (1989) to take the general trend toward a higher number of vacation days into account.

\section{Labour productivity}

For all European countries, the US and Switzerland, labour productivity was obtained by dividing value added by hours worked. For Japan, we used productivity per person in employment as provided by the OECD. 
To build confidence in the EU KLEMS database, we compared its productivity series to a coarser measure of sectoral productivity per person available from the OECD. The two sources yielded comparable data.

Net foreign assets

Data on net foreign assets were kindly provided by Gian Maria Milesi Ferretti, from the IMF. This dataset covers the 1970-2011 period and takes valuation effects into account explicitly.

\section{Terms of trade}

The individual countries' terms of trade are calculated as the ratio of export and import prices. The export and import prices are implicit National Accounts price deflators (i.e. the ratio of current and constant exports (imports) of goods and services) as provided by the World Bank's database, World Development Indicators (WDI).

\section{Output per capita}

Output per capita time series were taken from the World Bank's World Development Indicators.

\section{Government spending}

The individual countries' government consumption expenditures in percent of GDP are derived from the World Bank's database, World Development Indicators (WDI), i.e. "General government final consumption expenditure (\% of GDP)". Where needed the time series were extended based on the OECD Main Economic Indicators (MEI) database.

\section{Expressing variables}

In our analysis, each country's measure must be expressed in relative terms, with respect to the equivalent Swiss variable. For productivity differentials, terms of trade and output per capita, we work with the ratio

$$
\frac{X_{C H, t}}{X_{i t}}
$$


where $X_{i t}$ is used to represent the fundamental determinant of country $i$, and $X_{C H, t}$ is its Swiss equivalent. As far as net foreign assets and government consumption are concerned, the relative measure is computed as a difference:

$$
X_{C H, t}-X_{i t}
$$

These two variables, in fact, are already in percentage terms and enter our regression as such, whereas the former three terms enter in logs. Thus, coefficients on the set of variables in logs can be interpreted as elasticities of the real exchange rate with respect to each variable. Coefficients on the terms appearing in difference of levels, and not in logs, can instead be interpreted as the percent change in the real exchange rate corresponding to a 1 percentage point change in each variable.

When referring to the effective real exchange rate, we need equivalent "effective" measures of our explanatory variables. We build effective explanatory variables, $\tilde{X}_{t}$, based on the following arithmetic average:

$$
\tilde{X}_{t}=\prod_{i}(X)^{\omega_{i t}}
$$

where $\hat{X}$ is the variable expressed in relative terms as described above and $\omega_{i t}$ are the weights for all countries $i$. The weights are calculated as:

$$
\omega_{i t}=\frac{E X_{i t}^{C H}}{\sum_{i} E X_{i t}^{C H}}
$$

where $E X_{i t}^{C H}$ are Swiss exports to country $i$ in period $t$. 


\section{Additional Results}

Table D6 replicates the baseline regression of Table 6 without including Japan in the sample. The comparison of these results with the ones of columns 5 and 6 in Table 6 proves that the inclusion of Japan is crucial for the NFA and Y variables to be statistically significant.

Table D6: DOLS Regressions without Japan

\begin{tabular}{lcc}
\hline & \multicolumn{2}{c}{$\begin{array}{c}\text { Dep. variable: real exchange rate } \\
\text { (standard error in }\end{array}$} \\
& 5 & 6 \\
\hline & DOLS & DOLS \\
& 5 var. & 6 var. \\
& $1973-2011$ & $1973-2007$ \\
\hline BS & -0.263 & -0.275 \\
& $(0.178)$ & $(0.186)$ \\
G & 0.865 & $1.662^{*}$ \\
& $(0.817)$ & $(0.863)$ \\
Y & -0.258 & -0.152 \\
& $(0.184)$ & $(0.195)$ \\
NFA & 0.100 & 0.086 \\
& $(0.066)$ & $(0.074)$ \\
IV for TOT & $0.568^{* *}$ & $0.515^{*}$ \\
& $(0.285)$ & $(0.298)$ \\
\hline
\end{tabular}

\section{References}

Adler, Konrad, and Christian Grisse (2014), "Robustness of Estimates of Swiss Franc Equilibrium Exchange Rates to Alternative Modelling Assumptions", SNB Working Paper, N. 7.

Balassa, Bela (1964), "The Purchasing Power Parity Doctrine: A Reappraisal”, Journal of Political Economy, 72(6), pp. 584-596.

Baltagi, B.H., and C. Kao (2000), "Nonstationary Panels, Cointegration in Panels and Dynamic Panels: A Survey", in Advances in Econometrics: Nonstationary Panels, Panel Cointegration and Dynamic Panels, B. H. Baltagi, T. B. Fomsby and R. C. Hill, eds., Vol. 15, Oxford, Elsevier, pp.7-51. 
Bergstrand, Jeffrey H. (1991), "Structural Determinants of the Real Exchange Rate and National Price Levels: Some Empirical Evidence", The American Economic Review, 81(1), pp. 325-334.

Brunetti, Aymo (2008), „Die Wachstumspolitik des Bundes: Rückblick und Ausblick“, Die Volkswirtschaft, N. 4, pp. 4-7.

Brunetti, Aymo (2004), „Vom Wachstumsbericht zum Wachstumspaket“, Die Volkswirtschaft, N. 5, pp. 9-14.

Bussiere, Matthieu, Michele Ca' Zorzi, Alexander Chudik, and Alistair Dieppe (2010), "Methodological Advances in the Assessment of Equilibrium Exchange Rates", ECB Working Paper no. 1151.

De Bock, Reinout, and Irineu de Carvahlo Fihlo (2013), "The Behavior of Currencies during Risk-Off Episodes”, IMF Working Paper no. 13/8.

De Gregorio, José, Alberto Giovannini, and Holger Wolf (1994), "International Evidence on Tradables and Nontradables Inflation", European Economic Review, 38, pp. 1225-1244.

Dornbusch, Rudiger (1980), Open Economy Macroeconomics, Basic Books, New York.

Engel, Charles M. (1999), "Accounting for U.S. Real Exchange Rate Changes", Journal of Political Economy, 107, pp. 507-537.

Hamilton, James D. (1994), Time Series Analysis, Princeton University Press.

Hayashi, Fumio (2000), Econometrics, Princeton University Press.

International Monetary Fund (2013), External Balance Assessment (EBA) Methodology: Technical Background, Research Department.

International Monetary Fund (2006), Methodology for CGER Exchange Rate Assessments, Research Department.

Johansen, Soren (1995), Likelihood-Based Inference in Cointegrated Vector Autoregressive Models, Oxford University Press.

Kao, C., M. H. Chiang, and B. Chen (1999), "International R\&D Spillovers: An Application of Estimation and Inference in Panel Cointegration", Oxford Bulletin of Economics and Statistics, 61 (1), pp. 691-709.

Kohl, UlRICH (2004), Real GDP, "Real Domestic Income and Terms of Trade Changes", Journal of International Economics, 62, pp. 83-106.

Lane, Philip, and Gian Maria Milesi-Ferretti (2002), "External Wealth, the Trade Balance and the Real Exchange Rate", European Economic Review, 46(6), pp. 1049-1071.

Lane, Philip R., and Gian Maria Milesi-Ferretti (2006), “The External Wealth of Nations Mark II: Revised and Extended Estimates of Foreign Assets and Liabilities", pp. 1970-2004, IMF Working Paper, No. 06/69. 
Lee, Jaewoo, Gian Maria Milesi Ferretti, and Luca Antonio Ricci (2008), "Real Exchange Rates and Fundamentals: A Cross-Country Perspective", IMF Working Paper, No. 08/13.

Lenz, Carlos, and Marcel Savioz (2009), "Monetary Determinants of the Swiss Franc”, SNB Working Paper, no. 16.

Mark, N., and D. Sul (2003), "Cointegration Vector Estimation by Panel DOLS and Long Run Money Demand", Oxford Bulletin of Economics and Statistics, 65, pp. 665-680.

Neary, Peter (1988), "Determinants of the Equilibrium Real Exchange Rate", The American Economic Review, 78(1), pp. 210-215.

Ostry, Jonathan D. (1994), "Government Purchases and Relative Prices in a Two-Country World”, Economic Record, 70, 209, pp. 149-161.

Phillips, P., and H. Moon (2000), "Non-Stationary Panel Data Analysis: An Overview of some Recent Developments", Econometric Reviews, 19 (3), pp. 263-286.

Phillips, P., and H. Moon (1999), "Linear Regression Limit Theory for Nonstationary Panel Data”, Econometrica, 67 (5), pp. 1057-1111.

Ranaldo, Angelo, and Paul Soederlind (2010), Safe Haven Currencies, Review of Finance, 14, pp. 385-407.

Reynard, Samuel (2008), "What Drives The Swiss Franc", SNB Working Paper, no. 14.

Rogoff, Kenneth (1996), "The Purchasing Power Parity Puzzle”, Journal of Economic Literature, 34(2), pp. 647-668.

Saikkonen, P. (1991), "Asymptotically Efficient Estimation of Cointegration Regressions", Econometric Theory, 7, pp. 1-21.

Samuelson, Paul A. (1964), "Theoretical Notes on Trade Problems", Review of Economics and Statistics, 46(2), pp. 145-154.

Stock, James H., and Mark W. Watson (1993), "A Simple Estimator of Cointegrating Vectors in Higher Order Integrated Systems", Econometrica, 61, pp. 783-820.

Taylor, Alan M., and Mark P. Taylor (2004), "The Purchasing Power Parity Debate, Journal of Economic Perspectives”, 18(4), pp. 135-158. 


\section{SUMMARY}

We conduct an empirical investigation of the determinants of the Swiss franc real exchange rate. Theory and related empirical papers suggest various specific factors as potential determinants. We select some of these factors, and test their significance and magnitude in affecting the course of the CHF real exchange rate. Results stemming from a co-integration approach point to terms of trade and relative government spending as the most significant explanatory variables. Balassa-Samuelson effects do not play any significant role. Our results also confirm that this kind of empirical approach is sensitive to the choice of explanatory variables, panel countries and sample periods. 